\title{
A Rare Urinary Tract Infection Agent in a Dialysis Patient: Brevundimonas diminuta
}

\section{Diyaliz Hastasında Nadir Görülen Üriner Sistem İnfeksiyonu Etkeni: Brevundimonas diminuta}

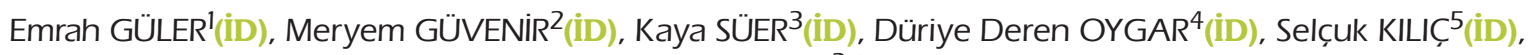 \\ Nedim ÇAKIR ${ }^{3}$ (ID)
}

\footnotetext{
${ }^{1}$ Department of Medical Microbiology and Clinical Microbiology, Near East University Faculty of Medicine, Nicosia, TRNC

${ }^{2}$ Health Services Vocational School, Near East University, Nicosia, TRNC

${ }^{3}$ Department of Infectious Diseases and Clinical Microbiology, Near East University Faculty of Medicine, Nicosia, TRNC

${ }^{4}$ Department of Nephrology, Near East University Faculty of Medicine, Nicosia, TRNC

${ }^{5}$ Department of Microbiology, Department of Reference Laboratory and Biological Products, General Directorate of Public Health, Ankara, Turkey
}

Cite this article as: Güler E, Güvenir M, Süer K, Oygar DD, Kılı̧ S, Çakır N. A rare urinary tract infection agent in a dialysis patient: Brevundimonas diminuta. FLORA 2021;26(1):216-9.

\begin{abstract}
Brevundimonas diminuta (B. diminuta), which is rarely held responsible for human infections, is known to cause serious infections such as bacteremia in addition to causing urinary tract infection and emphysema in immunosuppressed individuals. B. diminuta, creates difficulties in the treatment due to its wide antibiotic resistance. In our study, a 78-year-old male dialysis patient with type-2 diabetes mellitus and chronic renal failure (CRF) was presented. Upon detecting fever, cefixime was started for treatment. Brevundimonas diminuta/vesicularis was isolated from the urine culture and confirmed by MALDI-TOF (Matrix Assisted Laser Desorption lonizationTime Of Flight) to B. diminuta. Amikacin, imipenem, piperacillin/tazobactam (TZP) and trimethoprim/sulfamethoxazole (SXT) were found sensitive in manual antibiotic susceptibility test (AST). SXT was given to the patient, who did not respond to cefixime therapy, and the patient was cured. We think that, SXT, TZP and imipenem can be used in the treatment of B. diminuta infections where AST results cannot be obtained from automated systems.
\end{abstract}

Key Words: Dialysis; Infection; Brevundimonas diminuta 
ÖZ

\title{
Diyaliz Hastasında Nadir Görülen Üriner Sistem İnfeksiyonu Etkeni: Brevundimonas diminuta
}

\author{
Emrah GÜLER', Meryem GÜVENIR², Kaya SÜER ${ }^{3}$, Düriye Deren OYGAR ${ }^{4}$, Selçuk KILIÇ ${ }^{5}$, Nedim ÇAKIR ${ }^{3}$ \\ ${ }^{1}$ Yakın Dog̃u Üniversitesi Tıp Fakültesi, Tıbbi Mikrobiyoloji ve Klinik Mikrobiyoloji Anabilim Dalı, Lefkoșa, Kıbrıs \\ 2 Yakın Dog̃u Üniversitesi, Sag̃ılı Hizmetleri Meslek Yüksekokulu, Lefkoșa, Kıbrıs \\ 3 Yakın Dog̃u Üniversitesi Tıp Fakültesi, İnfeksiyon Hastalıkları ve Klinik Mikrobiyoloji Anabilim Dalı, Lefkoșa, Kıbrıs \\ ${ }^{4}$ Yakın Dog̃u Üniversitesi Tıp Fakültesi, Nefroloji Anabilim Dalı, Lefkoșa, Kıbrıs \\ ${ }^{5}$ Halk Sag̃lıg̃ı Genel Müdürlüg̃ü, Mikrobiyoloji Referans Laboratuvarı ve Biyolojik Ürünler Dairesi Bașkanlıg̃ı, Ankara, Türkiye
}

Nadiren insan infeksiyonlarından sorumlu tutulan Brevundimonas diminuta'nın (B. diminuta), immünsuprese kişilerde bakteriyemi gibi ciddi infeksiyonların yanında, idrar yolu infeksiyonu ve amfizeme de yol açtığı bilinmektedir. Fırsatçı bir bakteri olan B. diminuta, geniş bir antibiyotik direncine sahip olmasından dolayı tedavide zorluklar yaratmaktadır. Çalısmamızda, tip 2 diabetes mellitus ve kronik böbrek yetmezliği (KBY) olan 78 yaşındaki erkek diyaliz hastası ele alınmıştır. Hastada ateş $\left(38.1^{\circ} \mathrm{C}\right)$ görülmesi üzerine, tedavi için sefiksim 400 mg tablet başlandı. Yapılan idrar kültüründen Brevundimonas diminuta/vesicularis izole edildi ve MALDI-TOF (Matrix Assisted Laser Desorption lonization-Time Of Flight) ile B. diminuta konfirme edildi. Manuel antibiyotik duyarlılk testi (ADT)'nde amikasin, imipenem, piperasilin/tazobaktam (TZP) ve trimethoprim/sulfametoksazol (SXT) duyarlı olarak bulundu. Sefiksim tedavisine yanit vermeyen hastaya, elde edilen sonuçlar ışığında SXT verildi ve hastada iyileşme sağlandı. B. diminuta infeksiyonlarında, otomatize sistemlerden ADT sonucu alınamadığı durumda, SXT, TZP ve imipenem antibiyotiklerinin tedavide kullanılabileceğini düşünmekteyiz.

Anahtar Kelimeler: Diyaliz; Infeksiyon; Brevundimonas diminuta

\section{INTRODUCTION}

Brevundimonas spp., previously included in the Pseudomonas genus, is an aerobic, gram-negative bacillus, non-fermentative bacterial group with polar flagella. Brevundimonas vesicularis $(B$. vesicularis) is often held responsible for human infections, although several cases of Brevundimonas diminuta (B. diminuta) have been reported, which cause serious opportunistic infections, especially in immunocompromised patients ${ }^{[1]}$. These bacteria, which are commonly found in environmental conditions (water, soil, plants), are rarely isolated from clinical specimens. Human infections are generally seen in patients with cancer, cirrhosis and cystic fibrosis who are under treatment and have intravascular catheter ${ }^{[2,3]}$. It is stated in the literature that Brevundimonas species initially cause bacteremia and sepsis, less frequently pneumonia, endocarditis, keratitis, urinary tract infection and rarely arthritis and meningitis ${ }^{[4]}$.

Brevundimonas species, which are resistant to many antibiotics including beta lactam and fluoroquinolone groups, induce difficulties in treatment. On the basis of the cases, cephalospo- rins, penicillin and aminoglycoside antibiotics were applied to the patients and generally seen that the treatment was successful. In a study, all of the 30 Brevundimonas spp. isolated from the clinical specimens were $100 \%$ sensitive to piperacillin/tazobactam (TZP) and amikacin antibiotics, and 100\% resistant to ciprofloxacin and colistin $^{[4,5]}$. In our study, a case of urinary tract infection caused by a rare bacterium $B$. diminuta, in dialysis patient was presented.

\section{CASE REPORT}

A 78-year-old male patient with type-2 diabetes mellitus and chronic renal failure (CRF) has been entering the hemodialysis unit three times a week for nine years and discharging the residual urine by performing clean intermittent catheterization (CiC). The patient developed chills and fever $\left(38.1^{\circ} \mathrm{C}\right)$, systemic physical examination was performed and no signs other than suprapubic sensitivity was detected. Afterwards, as a urinary system infection was suspected, complete urinalysis test was requested. Urine and blood cultures were requested upon the detection of abundant leukocytes in complete urinalysis test. 
White blood cells were normal $\left(8.09 \times 10^{3} / \mathrm{uL}\right)$ in complete blood count, C-reactive protein (CRP) value was $5.25 \mathrm{mg} / \mathrm{dL}$ and cefixime $400 \mathrm{mg}$ tablet was started. In urine culture, gram-negative bacteria growth was observed in both blood and eosine methylene blue (EMB) agars (100.000 cfu/ $\mathrm{mL}$ ). Gram staining was done and gram-negative bacilli were seen under the microscope (Figure 1). Then, bacteria identification (Vitek 2 GN ID card) and antibiotic susceptibility test (AST) (Vitek 2 AST-N326 card) were performed using the bioMerieux Vitek 2 compact automatic system. AST was evaluated according to European Committee on Antimicrobial Susceptibility Testing (EUCAST) criteria. Bacteria were identified as Brevundimonas diminuta/vesicularis, but no AST result was obtained from the device. Amikacin, imipenem, TZP and trimethoprim/sulfamethoxazole (SXT) were sensitive, whereas betalactam group and fluoroquinolones were resistant in manual AST on Muller Hinton agar. Identification and AST were repeated twice. No reproduction was detected in blood culture. Due to the fact that it is a rare bacterium, the sample was sent to Republic

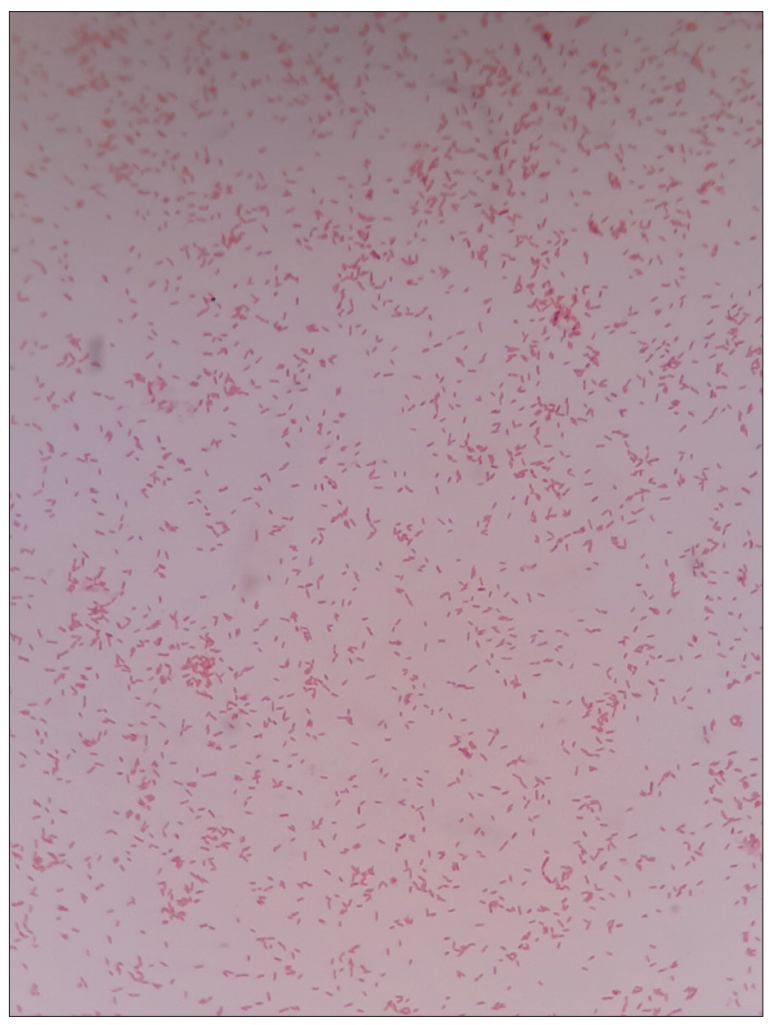

Figure 1. Gram staining of B. diminuta. of Turkey Ministry of Health, General Directorate of Public Health, Microbiology Reference Laboratory and Biological Products Department, Ankara, Turkey under appropriate conditions and confirmation of Brevundimonas diminuta was performed with Matrix Assisted Laser Desorption Ionization-Time Of Flight (MALDI-TOF). In the light of the results, SXT was given to the patient who did not respond to the treatment with cefixime, and the last treatment was successful by obtaining a clinical and laboratory response. No growth was detected in the patient's urine culture two weeks later.

\section{DISCUSSION}

Brevundimonas species are found in nature but rarely cause infection in humans. B. diminuta infections are reported in patients who have underlying diseases such as cirrhosis, cancer and cystic fibrosis $^{[3]}$. Generally, it is reported that $B$. diminuta can cause bacteremia but rarely play a role in serious infections such as spontaneous bacterial pleuritis ${ }^{[6]}$. There are also studies in the literature showing that it can cause urinary tract infection and emphysema ${ }^{[7]}$. In the study of Altunoren et al., B. diminuta peritonitis has been reported in a peritoneal dialysis patient ${ }^{[2]}$. On the other hand, Pandit et al. have reported that a 66-year-old woman case who has secondary $B$. diminuta keratitis after initial Pseudomonas aeruginosa infection ${ }^{[3]}$.

Broad spectrum antibiotic resistant Brevundimonas species are generally reported as sensitive to aminoglycoside group, TZP and imipenem antibiotics $^{[2,6]}$. In the study of Xiang et al., B. diminuta has been isolated in seven cancer patients and one of them was detected from the urine sample. In the same study, it was emphasized that all detected $B$. diminuta strains had multiple fluoroquinolone and cefepime resistance ${ }^{[8]}$. In another research, thirty Brevundimonas strains have been isolated, where they were $100 \%$ resistant to colistin and ciprofloxacin, but amikacin and TZP were detected sensitive in all the strains ${ }^{[5]}$. Nevertheless, in a study which evaluated 49 different studies involving Brevundimonas spp. infections, 71\% (n: 35) B. vesicularis and 29\% (n: 14) B. diminuta were detected. All strains were usually shown to be treated with cephalosporins, 
penicillin and aminoglycosides ${ }^{[4]}$. In our study, the detected strain was found to be sensitive to SXT, but resistant to ciprofloxacin, levofloxacin, ceftazidime, ceftriaxone and cefepime.

As a result, it is noted that $B$. diminuta can occasionally cause opportunistic infections, especially in immunosuppressed and catheterized patients. In some cases, it may not be possible to obtain AST from automated systems, since there is a limited number of article in the literature about this microorganism which is infrequently encountered during routine laboratory procedures. Although different results regarding antibiotic resistance were obtained, we think that SXT, TZP and imipenem antibiotics can be used in the treatment of $B$. diminuta infections.

\section{CONFLICT of INTEREST}

The authors have disclosed that they do not have any potential conflicts of interest.

\section{AUTHORSHIP CONTRIBUTIONS}

Concept/Design: NC, KS

Analysis/Interpretation: KS, MG, EG

Data Acquisition: DDO, SK

Writting: EG, KS

Revision and Correction: EG, MG

Final Approval: KS, EG

\section{REFERENCES}

1. Ghosh A, Chandratre K, Chaudhary A, Chaudhary S, Badani $N$, Chaudhary PS, et al. Whole-genome sequencing of Brevundimonas diminuta XGC1, isolated from a tuberculosis patient in Gujarat, India. Genome Announc 2015;3(3):e00686-15.
2. Altunören $O$, Güngör Ö, Güler S, Coșkun Yavuz Y, Bolat $H$, Inanç $E$, et al. A rare peritonitis cause in a peritoneal dialysis patient: Brevundimonas diminuta: case report. Turkiye Klinikleri I Nephrol 2015;10(1):10-3.

3. Pandit RT. Brevundimonas diminuta keratitis. Eye \& contact lens. 2012;38(1):63-5.

4. Ryan MP, Pembroke JT. Brevundimonas spp: Emerging global opportunistic pathogens. VIRULENCE 2018;9(1):48093.

5. Lee MR, Huang YT, Liao CH, Chuang TY, Lin CK, Lee SW, et al. Bacteremia caused by Brevundimonas species at a tertiary care hospital in Taiwan, 2000-2010. Eur J Clin Microbiol Infect Dis 2011;30:1185-91.

6. Lu B, Shi Y, Zhu F, Xu X. Pleuritis due to Brevundimonas diminuta in a previously healthy man. I Med Microbiol 2013;62:479-82.

7. Menuet $M$, Bittar F, Stremler N, Dubus JC, Sarles J, Raoult $D$, et al. First isolation of two colistin-resistant emerging pathogens, Brevundimonas diminuta and Ochrobactrum anthropi, in a woman with cystic fibrosis: a case report. J Med Case Rep 2008;2:373.

8. Han $X Y$, Andrade RA. Brevundimonas diminuta infections and its resistance to fluoroquinolones. J Antimicrob Chemother 2005;55:853-9.

\author{
Address for Correspondence/Yazıșma Adresi \\ Emrah GÜLER \\ Yakın Doğu Üniversitesi Tıp Fakültesi, \\ Tibbi Mikrobiyoloji ve \\ Klinik Mikrobiyoloji Anabilim Dalı, \\ Lefkosa-Kıbrıs \\ E-mail: emrahhhg@hotmail.co.uk
}

